\title{
EFEK EKSTRAK MELON (Cucumis melo) dan Gliadin TERHADAP KADAR Hb DAN HbCO TIKUS WISTAR JANTAN YANG DIPAPAR ASAP ROKOK
}

\author{
Yuyun Erlina Susanti' ${ }^{1}$, Bambang Wirjatmadi ${ }^{2}$ \\ IInstalasi Gizi RSUD Dr. Soetomo \\ 2Departemen Gizi Masyarakat, Fakultas Kesehatan Masyarakat, Universitas Airlangga \\ Alamat Korespondensi: \\ Yuyun Erlina Susanti \\ E-mail: yuyun.erlinayes@gmail.com
}

\begin{abstract}
The exposure of cigarette smoke produce CO bond in hemoglobin. Melon (Cucumis melo) and gliadin contains of antioxidants that prevent tissue damage. The aim of this study was to analyze the difference of hemoglobin and carboxyhemoglobin concentration in male Wistar rats were exposed to cigarette smoke and had been treated melon extract (Cucumis melo) and gliadin. The study was a laboratory experimental design, using Post Test Control Group Design Research and RAL method (Complete Randomize Design). The sample in this study were 25 male Wistar rats aged 3 months. The research was divided into 5 groups with 5 different treatment: control group, the treatment group were given exposure to cigarette smoke, the treatment group were given of cigarette smoke exposure and melon extract (Cucumis melo) and gliadin dose of $3 \mathrm{IU} /$ day, $4.5 \mathrm{IU} /$ day, and $9 \mathrm{IU} /$ day.The subject were divided into 5 groups each treated for 28 day. The sample size used Federer formula. The collection of data was obtained from the results of laboratory tests to hemoglobin and Carboxyhemoglobin. $\mathrm{Hb}$ and $\mathrm{HbCO}$ data collected and analyzed by Manova test at $95 \%$ confidence level. The results showed significant difference in average $\mathrm{Hb}$ and $\mathrm{HbCO}$ concentration (p-value $=0.000$ ) between male Wistar rats treated and not treated with melon extract (Cucumis melo) and gliadin. Melon extract has an effect on the decline of HbCO concentration due to exposure to cigarette smoke.
\end{abstract}

Keywords: smoke, melon extract, $\mathrm{Hb}, \mathrm{HbCO}$

\begin{abstract}
ABSTRAK
Paparan asap rokok menghasilkan ikatan CO terhadap hemoglobin. Melon (Cucumis melo) dan gliadin mengandung antioksidan yang mencegah kerusakan jaringan. Tujuan dari penelitian ini adalah menganalisis perbedaan kadar $\mathrm{Hb}$ and $\mathrm{HbCO}$ pada tikus wistar jantan yang dipapar asap rokok dan diberi ekstrak melon (cucumis melo) dan gliadin. Jenis penelitian ini adalah eksperimen laboratoris dengan menggunakan desain Control Group Post Test Design dengan menggunakan metode RAL (Rancangan Acak Lengkap). Sampel dalam penelitian ini sebanyak 25 ekor tikus wistar jantan usia 3 bulan. Penelitian ini dibagi menjadi 5 kelompok dengan perlakuan yang berbeda yaitu kelompok kontrol, kelompok perlakuan yang diberi paparan asap rokok, kelompok perlakuan yang diberi paparan asap rokok dan ektrak melon (Cucumis melo) dan gliadin dengan dosis sebanyak $3 \mathrm{IU} /$ hari, 4,5 IU/hari dan 9 IU/hari. Subyek dibagi 5 kelompok yang masing-masing mendapat perlakuan selama 28 hari. Data kadar $\mathrm{Hb}$ dan $\mathrm{HbCO}$ dikumpulkan dan dianalisis dengan uji Manova pada tingkat kepercayaan 95\%. Hasil penelitian menunjukkan ada perbedaan rerata kadar $\mathrm{Hb}$ dan $\mathrm{HbCO}$ (p-value $<0,05)$ pada tikus wistar jantan yang diberi perlakuan dan tidak diberi perlakuan ekstrak melon. Ekstrak melon berpengaruh terhadap penurunan kadar $\mathrm{Hb}$ dan $\mathrm{HbCO}$ akibat paparan asap rokok.
\end{abstract}

Kata kunci: asap rokok, ekstrak melon, $\mathrm{Hb}, \mathrm{HbCO}$ 


\section{PENDAHULUAN}

Merokok merupakan kebiasaan yang sangat dinikmati terutama lelaki dewasa (Trixie dkk, 2012). Menurut WHO (2014), hampir 6 juta kematian per tahun diakibatkan oleh asap rokok. Angka ini diperkirakan akan meningkat menjadi lebih dari 8 juta kematian pada tahun 2030. Kebiasaan merokok meningkatkan angka kematian pada penderita asma, pneumonia, influenza dan penyakit system pernapasan lainnya. Sebagian besar dari penderita COPD adalah akibat dari menghirup asap rokok (Hall, 2010).

Asap rokok mengandung sekitar 4 $\%$ karbon monoksida, yang cukup untuk meningkatkan kadar karboksihemoglobin darah seorang perokok sampai $10 \%$. Persentase ini cukup untuk mengganggu aktivitas dan kinerja mental (West, 2010).

Keadaan dimana sel / jaringan kekurangan oksigen disebut keadaan hipoksia. Hipoksia dapat disebabkan karena suplai oksigen berkurang akibat transport oksigen oleh hemoglobin terganggu. Kondisi dimana $\mathrm{Hb}$ tidak dapat berfungsi normal akibat terikat dengan $\mathrm{CO}$. $\mathrm{Hb}$ yang terikat dengan CO disebut carboxyhemoglobin (Soemiratdkk, 2009).

Hemoglobin mempunyai peran penting dalam mengikat, transportasi dan pengiriman oksigen ke seluruh jaringan tubuh yang membutuhkan (Ganong, 2003). Bila berikatan dengan oksigen maka hemoglobin akan menghasilkan pembentukan oksihemoglobin $\left(\mathrm{HbO}_{2}\right)$. Afinitas pengikatan hemoglobin terhadap oksigen dipengaruhi oleh $\mathrm{pH}$, suhu, dan konsentrasi 2,3-difosgliserat (2,3 DPG) dalam sel darah merah (Hall, 2010).

Kadar hemoglobin dalam darah adalah parameter yang digunakan mengukur anemia dari suatu individu. Karakteristik $\mathrm{CO}$ yang penting adalah kemampuan untuk mengikat hemoglobin. Hal ini dapat mengakibatkan pembentukan dari ikatan karboksi-hemoglobin ( $\mathrm{HbCO}$ ) yang bersifat 200 kali lebih stabil dibandingkan oksihemoglobin ( $\mathrm{HbO} 2) . K e r a c u n a n$ karbon monoksida menyebabkan penurunan kapasitas transportasi oksigen dalam darah oleh hemoglobin dan penggunaan oksigen di tingkat seluler (Amin, 2013).

Paparan asap rokok dapat meningkatkan radikal bebas dalam tubuh (Winarsi, 2007). Meningkatnya radikal bebas akan meningkatkan respon imun yaitu aktivasi sel inflamasi. Proses tersebut akan menghasilkan ROS (reactive oxygen species) berlebih, yang merupakan oksidan utama dalam tubuh (Harlev dkk, 2015). Senyawa radikal bebas yang berlebih dan berbahaya bagi tubuh dapat diredam dampak negativenya oleh anti-oksidan.

Melon (cucumis melo) mempunyai kandungan karotenoid melon yang tinggi yaitu 640 SI/100 BDD (Wirakusumah, 2006). Karotenoid berfungsi sebagai antioksidan yang menangkap radikal bebas dan membantu mencegah kerusakan jaringan (Olivia, 2006). Ekstrak melon (Cucumis melo) telah dikembangkan sebagai suplemen makanan yang memiliki kandungan SOD tinggi yaitu $100 \mathrm{U} / \mathrm{mg}$ yang dikombinasikan dengan gliadin untuk melindungi degradasi asam lambung dan membantu penyerapan di usus sehingga dapat dilepas secara bertahap ke dalam sirkulasi sistemik (Romao, 2015).

Hal ini membuktikan perlu adanya penelitian untuk mengetahui sejauh mana akibat paparan asap rokok dengan cara melihat konsentrasi terhadap kadar $\mathrm{Hb}$ dan HbCO pada hewan coba yang diberi ekstrak melon (Cucumis melo) dan gliadin untuk mencegah terhimpunnya senyawa oksidan secara berlebihan.

\section{METODE PENELITIAN}

Penelitian yang dilakukan adalah eksperimen laboratoris dengan menggunakan Control Group Post Test Design yaitu rancangan yang digunakan untuk mengukur efek paparan asap rokok terhadap kadar $\mathrm{Hb}$ dan $\mathrm{HbCO}$ pada tikus yang diberi ekstrak melon (Cucumis melo) dan gliadin pada kelompok eksperimen dengan cara membandingkan perlakuan dengan kelompok 
kontrol terhadap kadar HbCO. Untuk pengelompokan dan pemberian perlakuan menggunakan metode RAL (Rancangan Acak Lengkap).

Rancangan penelitian ini digunakan dengan parameter pengukuran variabel berupa kadar $\mathrm{Hb}$ dan kadar $\mathrm{HbCO}$. Perlakuan berupa paparan asap rokok pada tikus wistar jantan yang diberi dan tidak diberi ekstrak melon (Cucumis melo) dan gliadin.

Rancangan ini memungkinkan mengukur pengaruh perlakuan pada kelompok eksperimen dengan cara membandingkan kelompok tersebut dengan kelompok kontrol.

Sampel penelitian ini adalah tikus putih (Rattus novergicus strain wistar). Alasan pemilihan hewan coba tikus dikarenakan, pertama tikus adalah hewan coba yang sering digunakan karena kedekatannya dengan manusia. Keterdekatan tersebut antara lain adalah mamalia, pemakan campuran (omnivore), mudah berkembang biak dan mudah mendapat perlakuan.

Kriteria Inklusi pada penelitian ini adalah Tikus jenis Rattus novergicus strain wistar, Jenis kelamin jantan, Umur 3-4 bulan, Berat badan 150-250 gram, Warna bulu putih dan tikus aktif. Kriteria Eksklusinya adalah tikus yang selama penelitian tidak mau makan dan tikus yang kondisinya menurun atau mati selama penelitian berlangsung

Besar sampel ditentukan dengan menggunakan rumus Federer yaitu sebanyak 25 ekor tikus putih jantan (rattus novergicus strain wistar) yang dibagi secara random ke dalam 5 kelompok. Metode pengambilan sampel yang digunakan adalah Simple Random Sampling.

Sampel penelitian yang dibagi menjadi 5 kelompok perlakuan dapat dilihat pada Tabel 1.Pemeliharaan dan perlakuan serta pengambilan hasil kadar $\mathrm{Hb}$ dan $\mathrm{HbCO}$ dilakukan di Laboratorium Fakultas Kedokteran Universitas Airlangga Surabaya.

Penelitian dilaksanakan pada bulan April 2016 sampai Mei 2016. Penelitian membutuhkan waktu selama 5 minggu dan dibagi dalam dua bagian yaitu Minggu Adaptasi selama 7 hari dan Minggu Perlakuan selama 28 hari. Pada Minggu Adaptasi, hewan coba tikus akan dibiarkan beradaptasi tanpa diberikan perlakuan tambahan selain makanan dan minuman secara tak terbatas.

Kelompok Kontrol tidak diberikan paparan asap rokok. Kelompok Perlakuan dipapar asap rokok, pada kelompok III, IV dan $\mathrm{V}$ diberi ekstrak melon (Cucumis melo) dan gliadin dengan dosis yang berbeda.

Variabel yang diteliti adalah kadar $\mathrm{Hb}$ dan $\mathrm{HbCO}$ dalam darah tikus putih jantan galur Wistar dengan umur 3-4 bulan. Variabel independen yaitu pemberian antioksidan ekstrak melon dan gliadin.

Asap rokok yang dipaparkan pada hewan coba berasal dari asap rokok kretek tanpa filter dengan kandungan tar $38 \mathrm{mg}$ dan nikotin $2.2 \mathrm{mg}$ yang diberikan $1 \mathrm{x} /$ hari yaitu 1 batang rokok / pemaparan. Kadar $\mathrm{Hb}$ dan $\mathrm{HbCO}$ diukur dari serum darah. Ekstrak melon yang diberikan adalah ekstrak melon (SOD ekstrak melon + white protein matrix) $1 \mathrm{x} / \mathrm{hr}$ sesuai dosis perhitungan.

Perhitungan dosis dengan menggunakan tabel konversi perhitungan dosis yaitu pada tikus dengan berat 200 gram diasumsikan pada manusia $(70 \mathrm{~kg}$ ) didapatkan perhitungan $0,018 \times 250 \mathrm{IU}$ (dosis sehari) $=4,5 \mathrm{IU} /$ hari . Jadi dosis sehari yang dapat diberikan pada tikus putih jantan galur wistar adalah 4,5 IU/ hari pada hewan coba.

Tikus putih jantan galur Wistar diperoleh dari Fakultas Kedokteran Universitas Airlangga ditempatkan dalam kandang per kelompok dan diperlakukan secara baik dengan memenuhi aspek five freedom (5-F's) dan three R (3-Rs) (UU No 18,2009), Memiliki ventilasi yang baik, penyinaran normal, suhu dan kelembapan diperhatikan. Pembersihan kandang dan pergantian air minum dilakukan setiap hari. Pemberian makanan berupa pakan tikus standar dengan kadar protein $17 \%$ dan minuman diberikan secara ad libitum. 
Tabel 1 Perlakuan untuk masing-masing kelompok

\begin{tabular}{|c|c|}
\hline Kelompok & Perlakuan \\
\hline I & $\begin{array}{l}\text { Kelompok kontrol yang hanya } \\
\text { diberikan pakan tikus standar } \\
\text { dengan kadar protein } 17 \% \text { tanpa } \\
\text { adanya perlakuan berupa paparan } \\
\text { asap rokok dan pemberian ekstrak } \\
\text { melon (Cucumis melo) per oral. }\end{array}$ \\
\hline II & $\begin{array}{l}\text { Kelompok perlakuan yang } \\
\text { diberikan pakan tikus standar } \\
\text { dengan kadar protein } 17 \% \text { dan } \\
\text { perlakuan berupa paparan asap } \\
\text { rokok tetapi tanpa pemberian } \\
\text { ekstrak melon (Cucumis melo) } \\
\text { per oral }\end{array}$ \\
\hline III & $\begin{array}{l}\text { Kelompok perlakuan yang } \\
\text { diberikan pakan tikus standar } \\
\text { dengankadar protein } 17 \% \text { dan } \\
\text { perlakuan berupa paparan asap } \\
\text { rokok dan pemberian ekstrak } \\
\text { melon (Cucumis melo) per oral } \\
\text { dengan dosis } 3 \mathrm{IU} / \mathrm{hr} / \mathrm{ekor}\end{array}$ \\
\hline IV & $\begin{array}{l}\text { Kelompok perlakuan yang } \\
\text { diberikan pakan tikus standar } \\
\text { dengan kadar protein } 17 \% \text {, } \\
\text { perlakuan berupa paparan asap } \\
\text { rokok dan pemberian ekstrak } \\
\text { melon (Cucumis melo) per oral } \\
\text { dengan dosis } 4,5 \mathrm{IU} / \mathrm{hr} / \text { ekor. }\end{array}$ \\
\hline V & $\begin{array}{l}\text { Kelompok perlakuan yang } \\
\text { diberikan makanan, perlakuan } \\
\text { berupa paparan asap rokok } \\
\text { dan pemberian ekstrak melon } \\
\text { (Cucumis melo) per oral dengan } \\
\text { dosis } 9 \mathrm{IU} / \mathrm{hr} / \mathrm{ekor}\end{array}$ \\
\hline
\end{tabular}

Tikus sebelum digunakan penelitian dilakukan adaptasi atau diaklimitasi yaitu Minggu Adaptasi selama 7 hari dan Minggu Perlakuan selama 28 hari. Pada Minggu Adaptasi, hewan coba tikus akan dibiarkan beradaptasi tanpa diberikan perlakuan tambahan selain makanan dan minuman secara ad libitum.

Penelitian dilakukan selama 28 hari. Pada kelompok kontrol (I) tidak diberikan paparan asap rokok. Kelompok II-V dipapar asap rokok 1 batang sebanyak 1x/ hr. Kelompok III-V memperoleh perlakuan tambahan yaitu pemberian ekstrak melon (Cucumis melo) dan gliadin dengan dosis yang berbeda dengan menggunakan tabel konversi perhitungan dosis.

Pada hari ke 28 perlakuan, tikus diinjeksi anestesi. Tikus diinjeksi menggunakan ketalar secara intra muskuler pada paha tikus. Saat tikus dalam kondisi teranestesi, dilakukan pembedahan untuk mengambil darah dari jantung. Sampel darah disentrifuge selama 15 menit dengan kecepatan $3000 \mathrm{rpm}$, diambil serum darah untuk pemeriksaan kadar $\mathrm{Hb}$ dan $\mathrm{HbCO}$.

Alat yang digunakan dalam penelitian ini adalah kandang tikus beserta kelengkapan tempat makanan dan minuman, timbangan elektrik, sarung tangan, smoking pump, thermometer, tabung mikrohematokrit, tabung ependorf, timbangan analitik, sonde lambung, homogeneser, mikro pipet dan tip, water bath, vortex, tabung polypropylene, ice bath, sentrifuge, cartrideges C18, spektrofotometer untuk pemeriksaan kadar $\mathrm{HbCO}$, discetting kit, bak paraffin, kertas label, cover glass, object glass, oven, rotary microtome, staining kit, holder, cawan petri, pipet Pasteur, minyak emersi, dan mikroskop.

Bahan penelitian yang digunakan dalam penelitian ini adalah Tikus putih jantan galur Wistar dengan umur 3-4 bulan, ekstrak melon (Cucumis melo) dan gliadin, rokok kretek tanpa filter dengan kandungan $\operatorname{tar} 38 \mathrm{mg}$ dan nikotin $2.2 \mathrm{mg}$, pakan tikus standar dengan protein $17 \%$, air minum, ketalar, larutan TBA, methanol, aquades, formalin $10 \%$, alkohol $70 \%$ dan alkohol absolut.

Data kadar $\mathrm{Hb}$ dan $\mathrm{HbCO}$ yang terkumpul dianalisis dengan menggunakan analisis perbandingan antar kelompok dengan uji Manova dengan syarat data harus berdistribusi normal. Untuk mengetahui data berdistribusi normal dilakukan analisis normalitas dengan uji Kolmogorov-Smirnov, sedangkan untuk mengetahui varian data dilakukan uji homogenitas dengan uji Levence Test. Apabila terdapat perbedaan 
yang nyata atau sangat nyata antar perlakuan maka dilakukan uji LSD (Least Significance Difference). Untuk melihat seberapa besar perbedaan tiap kelompok perlakuan dengan tingkat kemaknaan $95 \%(p<0,05)$.

Penelitian ini telah mendapatkan sertifikat kaji etik dari komisi etik penelitian kesehatan dari Fakultas Kesehatan Masyarakat Universitas Airlangga Surabaya.

\section{HASIL}

\section{Kadar $\mathbf{H b}$}

Pada gambar 1 dapat dilihat rerata kadar $\mathrm{Hb}$ paling tinggi terdapat pada kelompok IV yaitu yang diberikan pakan standart dan perlakuan berupa ekstralk 4,5 IU/hr yaitu sebesar 14,70 $\pm 0,48$.

Grafik rerata kadar $\mathrm{Hb}$ dapat dilihat pada gambar 1. Berdasarkan uji statistik didapatkan data berdistribusi normal yaitu $p=0,760(p>0,05)$. Data pengukuran kadar $\mathrm{Hb}$ berdistribusi normal maka dilanjutkan dengan melakukan uji homogenitas varian (Levene Test).

Hasil Levene Test menunjukkan nilai signifikansi kadar $\mathrm{HbCO}$ adalah $p=0,166$. Hal ini berarti variabel tersebut memiliki varian yang sama sehingga dapat dianalisis dengan uji Manova. Nilai signifikansi kadar $\mathrm{Hb}$ lebih besar dibandingkan dengan nilai $\alpha=0,05$ yang berarti varian variabel dapat dikatakan homogen.

Perbedaan kadar $\mathrm{Hb}$ antara kelompok kontrol dan kelompok perlakuan dilakukan uji Manova dengan tingkat kepercayaan 95 $\%$ diperoleh pvalue $=0,002$, yang artinya minimal ada sepasang kelompok yang memiliki perbedaan rerata kadar $\mathrm{Hb}$.

Hasil LSD menunjukkan perbedaan rerata kadar $\mathrm{Hb}$ pada masing-masing kelompok yaitu : Variabel kadar $\mathrm{Hb}$ pada kelompok kontrol negatif menunjukkan ada perbedaan nyata antar kelompok kontrol negatif dengan kelompok kontrol positif, kelompok pemberian ekstrak melon (3 IU/ $\mathrm{hr})$.

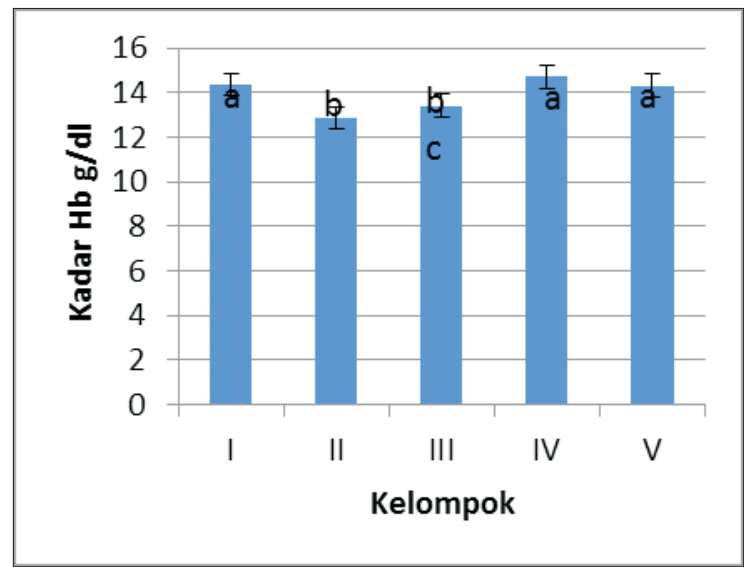

Gambar 1. Rerata $\mathrm{Hb} \rightarrow$

$$
\begin{aligned}
& \text { I : Kontrol Negative } \\
& \text { II : Kontrol Positif } \\
& \text { III :Ekstrak Melon 3IU/hr } \\
& \text { IV :Ekstrak Melon 4,5 IU/hr } \\
& \text { V : Ekstrak Melon } 9 \text { IU/hr }
\end{aligned}
$$

Variabel kadar $\mathrm{Hb}$ pada kelompok kontrol positif menunjukkan ada perbedaan nyata antar kelompok kontrol positif dengan kelompok kontrol negatif, kelompok pemberian ekstrak melon $(4,5 \mathrm{IU} / \mathrm{hr})$ dan pemberian ekstrak melon $(9 \mathrm{IU} / \mathrm{hr})$ dimana setiap kelompok ini memiliki nilai signifikansi $p=0,002 ; p=0,000$ dan $p=$ $0,003(p<0,005)$. Sedangkan pada kelompok kontrol positif dengan pemberian ekstrak melon (3 IU/hr) tidak ada perbedaan nyata dengan nilai signifikansi $p=0,193(p>$ $0,05)$.

Variabel kadar $\mathrm{Hb}$ pada kelompok pemberian ekstrak melon (3 IU/hr), menunjukkan ada perbedaan nyata antar kelompok pemberian ekstrak melon (3 IU/hr) dengan kelompok kontrol negatif, kelompok pemberian ekstrak melon (4,5 IU/hr), dan kelompok pemberian ekstrak melon (9 IU/ hr), setiap kelompok ini memiliki nilai signifikansi $\mathrm{p}=0,041 ; \mathrm{p}=0,007$ dan $\mathrm{p}=$ $0,049(\mathrm{p}<0,05)$. Sedangkan pada kelompok pemberian ekstrak melon (3 IU/hr) dengan kelompok kontrol positif tidak terdapat perbedaan nyata karena nilai signifikansi $\mathrm{p}$ $=0,193(\mathrm{p}>0,05)$. 
Variabel kadar $\mathrm{Hb}$ pada kelompok pemberian ekstrak melon (4,5 IU/hr), menunjukkan ada perbedaan nyata antar kelompok pemberian ekstrak melon (4,5 IU/ hr) dengan kelompok kontrol positif, dan kelompok pemberian ekstrak melon (3 IU/ hr), dimana setiap kelompok ini memiliki nilai signifikansi $p=0,000$ dan $p=0,007$ ( $p<$ $0,05)$. Sedangkan pada kelompok pemberian ekstrak melon (4,5 IU/hr) dengan kelompok kontrol negatif dan pemberian ekstrak melon (9 IU/hr) tidak terdapat perbedaan nyata karena nilai signifikansi $p=0,439$ dan $p=$ $0,388(p>0,05)$.

Variabel kadar Hb pada kelompok pemberian ekstrak melon (9 IU/hr), menunjukkan ada perbedaan nyata antar kelompok pemberian ekstrak melon (9 IU/ hr) dengan kelompok kontrol positif, dan kelompok pemberian ekstrak melon $(4,5$ $\mathrm{IU} / \mathrm{hr}$ ), setiap kelompok ini memiliki nilai signifikansi $p=0,003 ; p=0,049(p<0,05)$. Sedangkan pada kelompok pemberian ekstrak melon (9 IU/hr) dengan kelompok kontrol negatif dan kelompok pemberian ekstrak melon $(4,5 \mathrm{IU} / \mathrm{hr})$ tidak terdapat perbedaan nyata karena nilai signifikansi $p$ $=0,927$ dan $\mathrm{p}=0,214(p>0,05)$.

\section{Kadar HbCO}

Pada gambar 2 dapat dilihat rerata kadar $\mathrm{HbCO}$ paling tinggi terdapat pada kelompok kontrol positif yaitu yang diberikan pakan standart dan perlakuan berupa paparan asap rokok tetapi tanpa pemberian ekstrak melon, yaitu sebesar $9,77 \pm 0,81$.

Grafik rerata kadar $\mathrm{HbCO}$ dapat dilihat pada gambar 2. Berdasarkan uji statistik didapatkan data berdistribusi normal yaitu $p>0,05$. Data pengukuran kadar $\mathrm{HbCO}$ berdistribusi normal maka dilanjutkan dengan melakukan uji homogenitas varian (Levene Test).

Hasil Levene Test menunjukkan nilai signifikansi kadar $\mathrm{HbCO}$ adalah $p=0,879$. Hal ini berarti variabel tersebut memiliki varian yang sama sehingga dapat dianalisis dengan uji Manova. Nilai signifikansi kadar

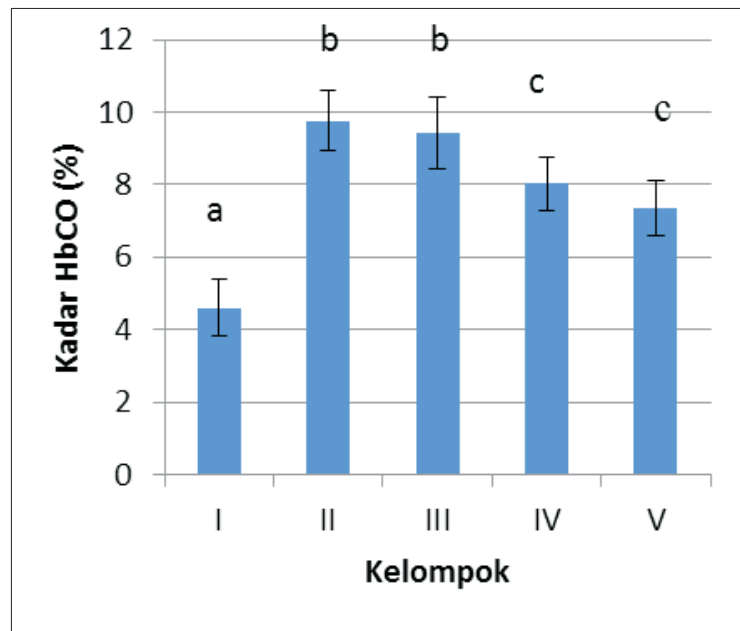

\footnotetext{
Gambar 2.Rerata $\mathrm{HbCO} \rightarrow$

I : Kontrol Negative

II : Kontrol Positif

III : Ekstrak Melon 3IU/hr

IV : Ekstrak Melon 4,5 IU/hr

V : Ekstrak Melon 9 IU/hr
}

$\mathrm{HbCO}$ lebih besar dibandingkan dengan nilai $\alpha=0,05$ yang berarti varian variabel dapat dikatakan homogen.

Perbedaan kadar $\mathrm{Hb} \mathrm{CO}$ antara kelompok kontrol dan kelompok perlakuan dilakukan uji Manova dengan tingkat kepercayaan $95 \%$ diperoleh pvalue = 0,000 , yang artinya minimal ada sepasang kelompok yang memiliki perbedaan rerata kadar $\mathrm{HbCO}$.

Hasil LSD menunjukkan perbedaan rerata kadar $\mathrm{HbCO}$ pada masing-masing kelompok yaitu : Variabel kadar $\mathrm{HbCO}$ pada kelompok kontrol negative menunjukkan ada perbedaan nyata antar kelompok kontrol negatif dengan kelompok kontrol positif, kelompok pemberian ekstrak melon (3 IU/ hr), pemberian ekstrak melon (4,5 IU/hr) dan pemberian ekstrak melon (9 IU/hr), setiap kelompok ini memiliki nilai signifikansi $p$ $=0,000(p<0,05)$.

Variabel kadar HbCO pada kelompok kontrol positive menunjukkan ada perbedaan nyata antar kelompok kontrol positif dengan kelompok kontrol negatif, kelompok pemberian ekstrak melon $(4,5$ IU/hr) dan pemberian ekstrak melon (9 IU/ 
hr) dimana setiap kelompok ini memiliki nilai signifikansi $p=0,000 ; p=0,003$ dan $p=0,000(p<0,005)$. Sedangkan pada kelompok kontrol positif dengan pemberian ekstrak melon (3 IU/hr) tidak ada perbedaan nyata dengan nilai signifikansi $p=0,505(p>$ $0,05)$.

Variabel kadar HbCO pada kelompok pemberian ekstrak melon (3 IU/hr), menunjukkan ada perbedaan nyata antar kelompok pemberian ekstrak melon (3 IU/hr) dengan kelompok kontrol negatif, kelompok pemberian ekstrak melon $(4,5 \mathrm{IU} / \mathrm{hr})$, dan kelompok pemberian ekstrak melon (9 IU/ hr), setiap kelompok ini memiliki nilai signifikansi $p=0,000 ; p=0,014$ dan $p=$ $0,001(p<0,05)$. Sedangkan pada kelompok pemberian ekstrak melon (3 IU/hr) dengan kelompok kontrol positif tidak terdapat perbedaan nyata karena nilai signifikansi $p$ $=0,505(p>0,05)$.

Variabel kadar HbCO pada kelompok pemberian ekstrak melon $(4,5 \mathrm{IU} / \mathrm{hr})$, menunjukkan ada perbedaan nyata antar kelompok pemberian ekstrak melon $(4,5$ $\mathrm{IU} / \mathrm{hr}$ ) dengan kelompok kontrol negatif, kelompok kontrol positif, dan kelompok pemberian ekstrak melon (3 IU/hr), dimana setiap kelompok ini memiliki nilai signifikansi $p=0,000 ; p=0,003$ dan $p=$ $0,014(p<0,05)$. Sedangkan pada kelompok pemberian ekstrak melon (4,5 IU/hr) dengan kelompok pemberian ekstrak melon (9 IU/hr) tidak terdapat perbedaan nyata karena nilai signifikansi $p=0,214(p>0,05)$.

Variabel kadar HbCO pada kelompok pemberian ekstrak melon (9 IU/hr), menunjukkan ada perbedaan nyata antar kelompok pemberian ekstrak melon (9 IU/hr) dengan kelompok kontrol negatif, kelompok kontrol positif, dan kelompok pemberian ekstrak melon (3 IU/hr), setiap kelompok ini memiliki nilai signifikansi $p=0,000 ; p=$ 0,000 dan $p=0,001(p<0,05)$. Sedangkan pada kelompok pemberian ekstrak melon $(9$ IU/hr) dengan kelompok pemberian ekstrak melon $(4,5 \mathrm{IU} / \mathrm{hr})$ tidak terdapat perbedaan nyata karena nilai signifikansi $p=0,214$ ( $p$ $>0,05)$.

\section{Hubungan antara Kadar Hb dan Kadar HbCO}

Hubungan antara Kadar $\mathrm{Hb}$ dan $\mathrm{Hb}$ CO menunjukkan adanya hubungan korelasi yaitu korelasi negative dan hubungan yang terjadi antara kedua kelompok ditunjukkan dengan data $\mathrm{r}=-0,483$ dan nilai signifikansi $p=0,014(<0,05)$.

\section{PEMBAHASAN}

Penelitian ini bertujuan untuk melihat apakah ada pengaruh paparan asap rokok terhadap kadar $\mathrm{Hb}$ dan kadar $\mathrm{HbCO}$ pada tikus wistar jantan yang diberi ekstrak melon (Cucumis melo). Hasil yang diperoleh dari penelitian ini secara preventif menunjukkan bahwa kelompok yang diberi paparan asap rokok disertai dengan pemberian ekstrak melon menunjukkan adanya kenaikan kadar $\mathrm{Hb}$ dan penurunan kadar $\mathrm{HbCO}$ dibandingkan dengan kelompok yang hanya dipapar asap rokok tanpa diberi ekstrak.

Kelompok yang hanya dipapar asap rokok didapatkan rerata kadar $\mathrm{Hb}$ sebesar 12,84 $\pm 0,84 \mathrm{gr} / \mathrm{dl}$ dan kadar HbCo 9,77 \pm $0,81 \%$. Kelompok perlakuan yang mendapat ekstrak melon didapatkan hasil rerata $\mathrm{Hb}$ tertinggi pada 4,5 IU/hr $(14,70 \pm 0,48 \mathrm{gr} / \mathrm{dl})$ dan rerata kadar $\mathrm{HbCO}$ terendah pada 9 IU/ hr $(7,55 \pm 0,97 \%)$.

Hal ini didukung penelitian Frank (2011) yang menyatakan adanya paparan asap rokok 3 kali sehari menunjukkan hasil $\mathrm{Hb}$ CO pada kelompok yang dipapar asap rokok mempunyai rerata $\mathrm{HbCO} 13,2 \pm 1,3 \%$.

Merokok terutama asap rokok, adalah determinan utama dari kadar $\mathrm{HbCO}$. Ada hubungan dosis-respons yang kuat antara jumlah rokok yang dihisap dan kadar $\mathrm{Hb}$ CO sampai 20 batang/hari, sejalan dengan penelitian sebelumnya pada pria di Inggris pada tahun 1975-1982 yang menunjukkan hubungan antara konsumsi rokok yang tinggi dengan kadar $\mathrm{HbCO}$ (Whincup et al, 2006). Hal ini menunjukkan bahwa akibat asap rokok pada konsumsi rokok yang tinggi menunjukkan kadar $\mathrm{Hb} \mathrm{CO}$ dapat memberikan prediksi resiko kardiovaskular. 
Radikal bebas yang terdapat pada asap rokok di dalam jumlah yang sangat tinggi dan memiliki sifat yang tidak stabil dapat merusak jaringan. Kelainan paru yang diakibatkan oleh radikal bebas yang terdapat pada rokok akan menyebabkan gangguan atau kelainan pada saluran pernafasan, mulai dari trakea, bronkus, dan bronkiolus sampai pada alveoli paru (Nurliani dkk, 2012).

Asap rokok akan merangsang peradangan pada sel dan produksi proteinase, keduanya yang terlibat dalam terjadinya emfisema dan bronchitis kronis. Selain itu, paparan asap rokok secara terus menerus diketahui sebagai pemicu penurunan elastisitas paru serta saluran nafas (Abboud dan Vimalanathan, 2008; Churg et al, 2008).

Karbon monoksida yang berikatan dengan hemoglobin dapat menggeser oksigen yang terikat pada hemoglobin dan mengikat $\mathrm{Hb}$ menjadi karboksi hemoglobin seperti pada reaksi berikut :

$$
\mathrm{HbO}_{2}+\mathrm{CO} \rightarrow \mathrm{HbCO}+\mathrm{O}_{2}
$$

Karena berikatan 250 kali lebih kuat daripada oksigen, karbon monoksida dalam jumlah kecil sudah dapat mengikat banyak hemoglobin dan membuat hemoglobin tidak dapat mengangkut oksigen (Hall, 2010). Keadaan hipoksemia kronik dapat meningkatkan pembentukan 2,3difosfogliserat, suatu senyawa yang berikatan dengan hemoglobin dan menurunkan afinitas hemoglobin terhadap oksigen (Hall, 2010).

Efek toksisitas utama adalah hasil dari hipoksia seluler yang disebabkan oleh gangguan transportasi oksigen. CO akan mengikat hemoglobin secara reversibel, yang akan menyebabkan anemia relative karena CO mengikat hemoglobin 230-270 kali lebih kuat daripada oksigen, yang menyebabkan ketersediaan oksigen untuk jaringan akan menurun. Kadar $\mathrm{Hb}$ CO 16 \% sudah dapat menimbulkan gejala klinis (Hall, 2010)

Salah satu jalur yang dapat berkontribusi padaefek kesehatan yang tidak diinginkan dari merokok adalah paparan oksidatifstres. Stres oksidatif disebabkan oleh asap rokok karena efek langsung dari radikal yang ada dalam asap. Adanya dan produksi dari radikal bebas dan oksigen reaktif lainnya dan spesies nitrogen (ROS dan RNS) dari asap rokok mungkin menjadi faktor penyumbang penyakit yang berhubungan dengan merokok. Asap rokok mampu memulai atau mempromosikan kerusakan oksidatif (Luchese dkk, 2009).

Asap rokok adalah biphasic (gas dan partikulat). Dalam fase gas, karbon monoksida dilepaskan dimana menjadi penyebab stress oksidatif, dan dalam fase partikulat, nikotin dan tar yang dilepaskan (Harlev, 2015).

Hemoglobin adalah sebuah biomolekul yang dapat mengikat oksigen. Hemoglobin akan dapat mengikat oksigen dengan cara mengambil oksigen dari paru-paru dan menyalurkan ke seluruh tubuh yang membutuhkan. Hemoglobin juga sebagai pengusung karbondioksida kembali menuju paru-paru untuk dihembuskan keluar tubuh. Hemoglobin adalah pigmen yang memberikan warna merah pada sel darah merah. Hemoglobin merupakan gabungan kelompok "heme" dan "globins" (protein). Hemoglobin terdiri dari empat proteindua globin rantai alpha dan dua rantaimasing beta dengan kelompok heme. Setiap hemoglobin memiliki dua rantai alpha ( $\alpha$ ) dan dua rantai beta ( $\beta$ ).Setiap rantai adalah sebuah subunit protein globular yang menyerupai myoglobin di rangka dan sel otot jantung. Seperti myoglobin, setiap rantai hemoglobin mengandung molekulheme, suatu pigmen non-protein kompleks. Setiap unit heme memiliki ion besi sehingga ionbesi tersebut bisa berikatan dengan molekul oksigen, membentuk oksihemoglobin $(\mathrm{HbO})$. Kelompok heme yang mengandung satu atom besi dapat mengikat satu molekul oksigen. Karena setiap molekul hemoglobin berisi empat globins, dapat membawa sampai empat molekul oksigen (Dean, 2005).

Keracunan karbonmonoksida dapat menyebabkan turunnya kapasitas transportasi 
oksigen dalam darah oleh hemoglobin dan penggunaan oksigen di tingkat seluler. Karbonmonoksida mempengaruhi berbagai organ di dalam tubuh, organ yang paling terganggu adalah yang mengkonsumsi oksigen dalam jumlah besar, seperti otak dan jantung (Soekamto, 2007). Hal ini dapat dilihat pada tingginya kadar $\mathrm{HbCO}$ pada paparan asap rokok yang tidak diberikan ekstrak melon.

Perlakuan pada hewan coba secara preventif dengan menggunakan ekstrak melon dapat mencegah penurunan kadar $\mathrm{Hb}$ dan kenaikan kadar $\mathrm{HbCO}$ yang diakibatkan oleh paparan asap rokok. Hal ini sejalan dengan penelitian Hall et al (2010) yaitu keadaan hipoksemia kronik dapat meningkatkan pembentukan 2,3difosfogliserat, suatu senyawa yang berikatan dengan hemoglobin dan menurunkan afinitas hemoglobin terhadap oksigen. Interaksi hidrofobik antaragliadin dan protein bisa mendefinisikan efektifitas secara oral dari SOD sehingga dihasilkan gliadin kombinasi monophasic/protein yang mampu menargetkan permukaan biologis enterosit (Calderon de la Barcaet al,1996) dan dapat meningkatkan penyerapan protein.

Hal ini sejalan dengan penelitian Nakajima et al (2009) yang menyatakan bahwa di usus, makrofag akan mengikat SOD ekstrak melon dan gliadin yang akan menstimulasi pelepasan NO ke dalam darah.

Melon (cucumis melo) mempunyai kandungan karotenoid melon yang tinggi yaitu 640 SI/100 BDD Karotenoid berfungsi sebagai antioksidan yang menangkap radikal bebas dan membantu mencegah kerusakan jaringan (Olivia, 2006). Pada bagian peroksisom dan glikosom di buah melon, terdapat juga aktifitas SOD (Winarsi, 2007).Ekstrak melon (Cucumis melo) telah dikembangkan sebagai suplemen makanan yang memiliki kandungan SOD tinggi yaitu $100 \mathrm{IU} / \mathrm{mg}$ yang dikombinasikan dengan gliadin untuk melindungi degradasi asam lambung dan membantu penyerapan di usus sehingga dapat dilepas secara bertahap ke dalam sirkulasi sistemik (Romao, 2015).

Enzim SOD melindungi sel-sel tubuh dan mencegah terjadinya proses peradangan yang diakibatkan oleh radikal bebas. Aktivitas enzim SOD memiliki peran penting dalam sistem pertahanan tubuh, terutama terhadap aktivitas senyawa oksigen reaktif yang dapat menyebabkan stress oksidatif (Wolfgang dkk, 2014). Gliadin gandum biopolymeric sebagai molekul aktif digunakan untuk melindungi terhadap proses pencernaan (Renard dkk, 2002), berinteraksi dengan penyerapan pada epitel usus sehingga dapat melakukan pengiriman mukosa dari molekul aktif (Fassano dkk, 2000).

Hal ini juga sejalan dengan penelitian Romao (2015) yang menyatakan bahwa sejak tahun 2000, ekstrak melon dengan SOD yang diperkaya secara alami telah dikembangkan untuk digunakan sebagai suplemen makanan. Peningkatan aktivitas SOD endogen untuk tikus yang diberi SOD ekstrak melon dan gliadin selama 28 hari dapat mempengaruhi kelangsungan hidup sel. Hal ini ditunjukkan oleh penurunan apoptosis hepatosit dan peningkatan resistensi terhadap hemolisis dari eritrosit dan depolarisasi membran mitokondria.

Romao (2015) juga menjelaskan bahwa ekstrak melon SOD dan gliadin memiliki efek menguntungkan pada keadaan dengan kebutuhan tubuh yang tinggi. Bioactive antioksidan mungkin mewakili peningkatan kualitas hidup yang bermakna.

Hubungan antara kadar $\mathrm{Hb}$ dan $\mathrm{HbCO}$ juga menunjukkan hubungan yang non linear atau negatif yaitu penurunan nilai $\mathrm{Hb}$ seiring dengan kenaikan $\mathrm{HbCO}$, begitu juga sebaliknya.

Kesimpulan dari penelitian ini adalah bahwa paparan asap rokok dapat menurunkan kadar $\mathrm{Hb}$ dan meningkatkan kadar $\mathrm{HbCO}$ dalam tubuh. Pemberian antioksidan yang berasal dari ekstrak melon (Cucumis melo) dangliadin sesuai dengan dosis (250 IU/hr) dapat digunakan secara signifikan untuk menurunkan kadar $\mathrm{HbCO}$ dalam tubuh. 


\section{SIMPULAN}

Pemberian (Cucumis melo) dan gliadin selama 28 hari secara signifikan memperlihatkan pengaruh pada kenaikankadar $\mathrm{Hb}$ dan penurunan kadar $\mathrm{HbCO}$ pada tikus wistar jantan yang diberi paparan asap rokok. Namun perlu dilakukan penelitian lebih lanjut terhadap (Cucumis melo) dangliadindengan waktu yang lebih lama untuk dapat menghambat atau meniadakan pembentukan $\mathrm{HbCO}$.

Ekstrak melon (Cucumis melo) dan gliadin dapat diberikan pada perokok aktif maupun pasif dengan dosis 1 kali $250 \mathrm{IU} / \mathrm{hari}$ sebagai antioksidan yang berperan dalam penurunan radikal bebas dalam darah. Untuk pemerintah perlu adanya daerah kawasan bebas rokok berdasarkan efek merugikan yang ditimbulkan oleh asap rokok terhadap kesehatan.

\section{DAFTAR PUSTAKA}

Abboud, R.T., Vimalanathan, S., (2008) Pathogenesis of COPD. Part I. The role ofprotease-antiprotease imbalance in emphysema. Int. J. Tuberc. Lung Dis. 12 : 361-367.

Amin M. 2013. Pemeriksaan dan Interpretasi Faal Paru.PKB Pulmonologi dan Ilmu Kedokteran Respirasi.Surabaya : FK Unair.

Calderon D. B, Yepiz-Plascencia, , BøgHanse N,. 1996. Hydrophobic interactions between gliadin and proteins and celiacdisease. Journal of Life Sciences. Vol.23 : 1951-1960.

Churg, A., Cosio, M., Wright, J.L., (2008) Mechanisms of cigarette smokeinducedCOPD: insights from animal models. Am. J. Physiol. Lung Cell Mol. Physiol. 294 : 612-631.

Dean L. 2005. National Center for Biotechnology Information (NCBI), National Library of Medicine, National Institutes of Health, Bethesda, MD 208926510.http://www.ncbi.nlm.nih.gov/books/ NBK2263. Sitasi tanggal 2 Maret 2016.
Fassano, A., Not, T., Wang, W., Uzzau, S., Berti, I., Tommasini, A.,Goldblum, S.E. 2000. Zolunin, a newly discovered modulator of in-testinal permeability, and its expression in celiac disease. Journal of Lancet. Vol.355:1518-1519.

Ganong W.F. 2003.Buku ajar Fisiologi Kedokteran. Jakarta : EGC.

Hall, E.J. 2010.Buku Saku Fisiologi Kedokteran Guyton \& Hall.Ed.11. Jakarta : EGC.

Harlev A., Ashok A, Sezgin O. G, Amit S. and Stefan S.P. 2015. Smoking and Male Infertility : An Evidence-Based Review. World Journal Mens Health. Vol.33 (3) : 143-160.

Luchese, C., Simone P, Nogueira C.W,. 2009. Brain and lungs of rats differently affected by cigarette smoke exposure : Antioxidant effect of an organoselenium compound. Journal of Pharmacological Research. Vol. 59 : 194-201.

Nurliani, A., Santoso, dan Rusmiati. (2012). Efek Antioksidan Ekstrak Bulbus Bawang Dayak (Eleutherine palmifolia) Pada Gambaran Histopatologi Paru-Paru Tikus Yang Dipapar Asap Rokok.Jurnal Bioscientiae Volume 9, Nomor 1, Halaman : 60-69.

Olivia F., Alam S., Hadibroto I. 2006. Seluk Beluk Food Suplement.Jakarta : PT Gramedia Pustaka Utama.

Renard, D., Robert, P., Lavenant, L., Melcion, D., Popineau, Y., Gueguen,J., Duclairoir, C., Nakache, E., Sanchez, C., Schmitt, C. 2002. Biopolymericcolloidal carriers for encapsulation or controlled release applications. .International Journal of Pharmaceutics. Vol.242 : 163-166

Romao S. 2015. Theraupetic value of oral sup;ementation with melon superoxide dismutase and wheat gliadin combination. Nutrition Journal. Vol. 31 : 430-436.

Soemirat J.D., Roosmini, Indah R.S.S., Khatarina O. (2009). Toksikologi Lingkungan. Yogyakarta : Gadjah Mada University Press.

West, John B. (2010). Patofisiologi Paru Esensial.Ed.6.Jakarta : EGC. 
WHO. 2014. Global Youth Tobacco Survey. http://www.who.int/tobacco/surveillance/ gyts/en. Sitasi tanggal 24 Februari 2016.

Whincup P., Papacosta O., Lennon L., Haines A. 2006.

Carboxyhaemoglobin levels andtheir determinants in older British men. Journal BMC Public Health. Vol.6:189

Winarsi,H. 2007. Antioksidan Alami \& Radikal Bebas. Potensi dan Aplikasinyadalam
Kesehatan. Cetakan ke-4. Yogyakarta : Penerbit Kanisius.

Wirakusumah, E.S,. 2006. Buah dan Sayur Untuk Terapi.Jakarta : Penebar Swadaya.

Wolfgang D., Karl O., Wilfried R. 2014. Oxidative Stress and Free Radicals in COPD - Implications and Relevance for Treatment.Int.Journal Chron Obstruct Pulmon Dis.NCBI. Vol.9 : 1207 - 1224. 